\title{
Sink or link? The bacterial role in benthic carbon cycling in the Arabian Sea's oxygen minimum zone
}

\author{
L. Pozzato ${ }^{1}$, D. Van Oevelen ${ }^{1}$, L. Moodley ${ }^{2}$, K. Soetaert ${ }^{1}$, and J. J. Middelburg ${ }^{3}$ \\ ${ }^{1}$ Department of Ecosystem Studies, Royal Netherlands Institute for Sea Research NIOZ-Yerseke Korringaweg 7, \\ 4401CT Yerseke, the Netherlands \\ ${ }^{2}$ International Research Institute of Stavanger (IRIS), Mekjarvik 12, 4070 Randaberg, Norway \\ ${ }^{3}$ Department of Earth Sciences-Geochemistry Faculty of Geosciences, Utrecht University Budapestlaan 4, 3584 CD \\ Utrecht, the Netherlands
}

Correspondence to: L. Pozzato (larapozzato79@gmail.com)

Received: 6 May 2013 - Published in Biogeosciences Discuss.: 26 June 2013

Revised: 16 September 2013 - Accepted: 19 September 2013 - Published: 2 November 2013

\begin{abstract}
The bacterial loop, the consumption of dissolved organic matter (DOM) by bacteria and subsequent transfer of bacterial carbon to higher trophic levels, plays a prominent role in pelagic food webs. However, its role in sedimentary ecosystems is not well documented. Here we present the results of isotope tracer experiments performed under in situ oxygen conditions in sediments from inside and outside the Arabian Sea's oxygen minimum zone (OMZ) to study the importance of the microbial loop in this setting. Particulate organic matter, added as phytodetritus, was processed by bacteria, protozoa and metazoans, while dissolved organic matter was processed only by bacteria and there was very little, if any, transfer to higher trophic levels within the 7 day experimental period. This lack of significant transfer of bacterial-derived carbon to metazoan consumers indicates that the bacterial loop is rather inefficient, in sediments both inside and outside the OMZ. Moreover, metazoans directly consumed labile particulate organic matter resources and thus competed with bacteria for phytodetritus.
\end{abstract}

\section{Introduction}

Isotope tracer experiments have been conducted in various settings to assess the processing of particulate labile organic matter (OM) by the benthic community (Blair et al., 1996; Levin et al., 1997; Moodley et al., 2002, 2005b; Witte et al., 2003a, b; Andersson et al., 2008; Woulds et al., 2009). These studies have revealed that all benthic size classes (bac- teria, meiofauna, and macrofauna) were involved and took up some of the labelled OM. In some cases (e.g. in the deep Sognefjord and in the Porcupine Abyssal Plain), bacterial and meiofaunal response to a fresh input of OM was retarded when compared to macrofaunal reaction and it was suggested (Witte et al., 2003a, b) that the offered phytodetritus had to be processed in macrofaunal gut before being available to the micro- and meio-biota. These results, although very informative, left some questions largely unanswered, especially for hypoxic areas: is organic matter assimilated directly by meio- and macrofauna feeding on phytodetritus, or indirectly via ingestion of bacteria that in turn hydrolysed particulate organic matter (POM) into dissolved organic matter (DOM) and subsequently incorporated it? Are bacteria therefore a major food source for sedimentary fauna or are they a minor resource? In other words, are bacteria a link or a sink in the benthic food web?

Pomeroy (1974) suggested that bacteria and protozoa in pelagic ecosystems form an important link between dissolved organic matter produced by primary producers and metazoans higher up in the food web. Following studies confirmed this hypothesis and Azam et al. (1983) named this pathway the "microbial loop" in pelagic ecosystems. Later, Jumars et al. (1989) presented a provocative paper in which this theory was further elaborated: they showed that heterotrophic bacteria were feeding not only on phytoplanktonderived dissolved organic carbon but also on DOM derived from sloppy feeding by zooplankton. 
Lee (1980) and Kemp (1988) were among the first to hypothesize that the microbial loop might also be occurring in the sediment, although possibly in a more complex form. According to these authors, sediment bacteria would incorporate DOM via their membranes directly from the pore water or from polymeric materials and particles, after breaking them down to more simple compounds using exoenzymes. Bacteria would then become food for protozoans and metazoans and thereby play a key role in the transfer of carbon and nutrients. Lee (1992) conducted ${ }^{14} \mathrm{C}$ incubation experiments using water samples from an enclosed marine basin to study carbon preservation under oxic and anoxic conditions. She found that differences in OM decomposition rates between oxic and anoxic settings were very small, but that anoxic sediments nevertheless showed high OM preservation. Lee (1992) suggested that, where bacterial grazers are absent, organic matter in anoxic systems may be sequestered as bacterial biomass, or as bacterially derived products. Therefore, she concluded that biomass and biodiversity of bacterial grazers may explain part of the differences in carbon preservation between oxic and anoxic settings, supporting the idea of a benthic microbial loop and offering some insights in the relationships between bacteria and their grazers and a link with bottom-water oxygen levels.

Recent observations on the trophic role of bacteria and bacterial-derived carbon in sediments based on isotope tracer experiments revealed however that bacteria are not a major carbon source for intertidal benthos (Van Oevelen et al., 2006b). Consistently, for deep-sea sediments Nomaki et al. (2006) and Guilini et al. (2010) found limited to no bacterivory by meiofaunal foraminifera and nematodes, previously thought to be major consumers of bacterial production. If faunal grazing does not constitute a main controlling factor of the bacterial community, then the latter must be controlled in a different way. Danovaro et al. (2008) proposed viral infection as a heterotrophic bacterial production controlling mechanism in the sediment, asserting that at water depths beneath $1000 \mathrm{~m}$, viral lysis would be responsible for nearly all prokaryotic mortality, transforming bacteria in detritus. The viral shunt hypotheses and the results obtained in bacterivory studies suggest that the microbial loop in sediments is a sink rather than a link in the benthic food web.

The importance of the microbial loop in deep-sea benthic food webs has however been exclusively studied in sediments underlying oxic bottom waters. Oxygen minimum zones (OMZ) are known for their different biogeochemistry as compared to regular oxic settings. The naturally occurring OMZ in the Arabian Sea is an archetypical example: here OM accumulates in the sediment (Cowie et al., 1999; Middelburg and Levin, 2009). Several explanations have been given for this accumulation: low faunal biomass (Demaison and Moore, 1980; Levin et al., 1991; Jeffreys et al., 2009) and faunal activity (Woulds et al., 2007; Levin et al., 2009), lack of oxidants and interaction of the OM with inorganic material (Hedges and Keil, 1995), incorporation of organic particles in geomacromolecules or humic substances (Mayer, 1994), and the refractory nature of the OM deposited at the bottom (Henrichs, 1992). Focusing on the functioning of this ecosystem, results by Moodley et al. (2011), Pozzato et al. (2013) and Koho et al. (2013) showed that limited faunal activity, low oxygen concentrations and low faunal biomass cannot explain on their own the OM accumulation. Instead, community functioning (in terms of trophic relationships and food preferences) and efficiency in OM processing are more likely to be key factors in determining such phenomenon.

We investigated the specific role of bacteria in the sediments of the Arabian Sea's OMZ to clarify if they are a sink or a link in the benthic food web and whether this differs between sediments underlying oxygenated or low-oxygen bottom waters. We amended sediment from inside and outside the Arabian Sea's OMZ with two different complex OM tracers, POM and DOM. This approach allowed us to follow the two main routes of OM degradation in the benthic food web: POM degradation by bacteria and metazoans, i.e. the detritivore pathway (Mayer, 1989; Chrost, 1991a, b), and DOM incorporation by bacteria which in turn are subsequently grazed by fauna, i.e. the microbial loop. While it is clear that anoxic sediments lacking metazoans do not support a microbial loop, it is unknown whether the benthic microbial loop is more or less efficient in OMZ sediment with substantial faunal biomass as found in the Arabian Sea. In such sediments the relatively high quantity of refractory OM (preferentially degraded by bacteria) support secondary production of microbes which then might be assimilated by the specialized fauna of OMZ sediments. Should the microbial loop play a key role in benthic ecosystems, one would then expect it to be prominent in fauna-bearing, low-oxygen, organic-rich sediments such as found in the Arabian Sea's OMZ.

\section{Material and methods}

\subsection{Study area}

The study focused on two stations on the Murray Ridge, situated in the northern Arabian Sea between the Indus River delta and the city of Muscat (Fig. 1) and was carried out in January 2009, during the winter monsoon season. Station STOMZ lies in the core of the OMZ and was shallower $\left(22^{\circ} 32.9^{\prime} \mathrm{N}, 64^{\circ} 02.4^{\prime} \mathrm{E}, 885 \mathrm{~m}\right)$ than the deeper station SToutOMZ $\left(22^{\circ} 18.5^{\prime} \mathrm{N}, 63^{\circ} 24.5^{\prime} \mathrm{E}, 1791 \mathrm{~m}\right)$ at the lower boundary of the OMZ. The same stations have been investigated in detail for organic geochemistry (Koho et al., 2013), pore-water geochemistry (Kraal et al., 2012) and for particulate organic carbon processing (Pozzato et al., 2013). The latter companion study focussed on the effect of bottom-water oxygen manipulation on community processing of particulate organic carbon and the controls of this and that study are identical. 

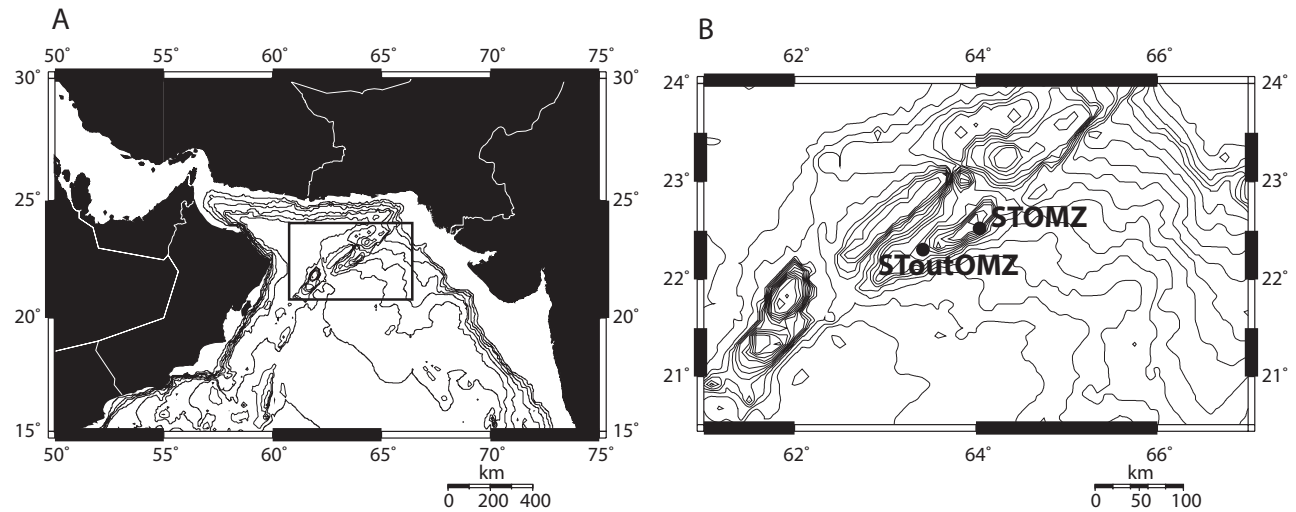

Fig. 1. The northern Arabian Sea (A) and the sampling areas STOMZ and SToutOMZ indicated on the Murray Ridge (B) after Pozzato et al. (2013).

The Murray Ridge is located southwest of the Pakistan margin and it starts about $100 \mathrm{~km}$ from the coast into the Arabian Sea; it is approximately $20 \mathrm{~km}$ wide and $750 \mathrm{~km}$ long. The Ridge is composed of three different parts: the southern crest at water depth $<1000 \mathrm{~m}$, the northern zone is subdued with water depths of $2000 \mathrm{~m}$ and the $>4400 \mathrm{~m}$ deep Dalymple Trough (Gaedicke et al., 2002). The sedimentary cover of the Ridge increases in thickness towards the coast and it progressively widens. The Ridge is a perfect experimental setting to study marine OM processing because it is isolated and far away from shore (Shimmield et al., 1990), preventing confounding terrestrial input to this site. The OMZ starts approximately $150 \mathrm{~m}$ below the sea surface and coincides with the seasonal thermocline. At STOMZ a surface mixed layer was recorded by our CTD (conductivity-temperature-depth sensor) at depth between 80 and $85 \mathrm{~m}$, whereas the water column at SToutOMZ was fully mixed.

Three different methods were used to analyse the oxygen concentration in the water column: the oxygen sensor on the CTD, Winkler titration of the water sampled by the rosette sampler and an optode fitted to the multicorer. The CTD was equipped with a Sea-Bird SBE43 sensor, detection limit $3 \mu \mathrm{mol} \mathrm{L}{ }^{-1}$, accuracy $2 \%$, which was calibrated using Winkler titration of samples from outside the OMZ. One CTD cast was done per station. Sea surface temperature was $25.2^{\circ} \mathrm{C}$ and below the mixed layer the temperature declined to a minimum of $2.1^{\circ} \mathrm{C}$ at $2600 \mathrm{~m}$. Salinity profiles showed a distinct maximum of 36.2 at $320 \mathrm{~m}$, probably related to the Persian Gulf outflow. The salinity decreased below $400 \mathrm{~m}$ to a minimum of 34.7 at $3000 \mathrm{~m}$.

\subsection{Preparation of isotopically labelled substrates}

POM and DOM were prepared in the laboratory from axenic cultures of the brown diatom Thalassiosira pseudonana that were grown in a $30 \%{ }^{13} \mathrm{C}-\mathrm{NaHCO}_{3}$ enriched $\mathrm{F} 2$ medium. Algae were harvested via centrifugation ( $2000 \mathrm{~g}$ force), the pellet washed of any residual label with artificial seawater and centrifuged again. The pellets were frozen at $-80^{\circ} \mathrm{C}$ and freeze-dried. We harvested $\sim 0.8 \mathrm{~g}$ dry algae from $9 \mathrm{~L}$ of cultured Thalassiosira pseudonana. Sterilized Milli-Q water was then added to the freeze-dried pallets to burst the algal cells and release the inner cytoplasm and exudates from the algal frustules. DOM was separated from POM by centrifugation $(2000 \mathrm{~g}$ force). This procedure was repeated three times. The remaining pellet was used as POM substrate. The supernatant was taken as DOM substrate and was filtered through a GF/F pre-combusted filter, filtered through a $0.2 \mu \mathrm{m}$ syringe filter before being stored in glass vials. Both POM and DOM were portioned, frozen and freeze-dried again before usage in the experiments. The ${ }^{13} \mathrm{C}$ content of the POM was $20 \%$ (equal to a $\delta^{13} \mathrm{C}$ value of $21500 \%$ ) and $18 \%$ of the DOM (equal to a $\delta^{13} \mathrm{C}$ of $18500 \%$ ) as measured by a Thermo Electron Flash EA 1112 analyser (EA) coupled to a Delta V isotope ratio mass spectrometer (IRMS).

\subsection{Sediment core sampling}

Intact $10 \mathrm{~cm}$ i.d. (internal diameter) multicorer cores were retrieved. A total of ten cores per station was collected: two were used for sediment characteristics, four were incubated for seven days and four were used as control to sample for bacterial and fauna isotopic background values and biomass. Upon arrival on deck, the two cores used for sediment characteristics determination were sliced immediately, the others were used for incubation or as controls. They were transferred to a temperature-controlled laboratory and were allowed to acclimatize for 2 days in a water bath at in situ temperature. During this period, the overlying water of the cores was gently bubbled with pre-made air mixtures (certified $\mathrm{O}_{2}$, $\mathrm{CO}_{2}$ and $\mathrm{N}_{2}$ gas mixture by Hoekloos BV, the Netherlands) to give oxygen concentrations of $125 \mu \mathrm{M} \mathrm{O} \mathrm{O}_{2}$ for SToutOMZ and $6 \mu \mathrm{M} \mathrm{O}_{2}$ for STOMZ (Pozzato et al., 2013); these conditions were maintained and monitored during incubation. 
Table 1. Station locations, environmental parameters, water and sediment characteristics of the two sampling stations, STOMZ and SToutOMZ (after Pozzato et al., 2013).

\begin{tabular}{lcc}
\hline & STOMZ & SToutOMZ \\
\hline Position & $22^{\circ} 32.9^{\prime} \mathrm{N}, 64^{\circ} 02.4^{\prime} \mathrm{E}$ & $22^{\circ} 18.5^{\prime} \mathrm{N}, 63^{\circ} 24.5^{\prime} \mathrm{E}$ \\
Depth & $885 \mathrm{~m}$ & $1791 \mathrm{~m}$ \\
Bottom water & 10 & \\
Temperature ${ }^{\circ} \mathrm{C}(\mathrm{CTD}$ sensor $)$ & 34.8 & 4 \\
Salinity $(\mathrm{CTD}$ sensor $)$ & 2 & 45.9 \\
Dissolved $\mathrm{O}_{2} \mu \mathrm{mol} \mathrm{kg}{ }^{-1}(\mathrm{CTD}$ sensor $)$ & & \\
Sediment & 35.4 & 16.5 \\
Median grain size $\mu \mathrm{m}(0-3 \mathrm{~cm})$ & 6.38 & 1.03 \\
$\%$ Total organic carbon $(0-3 \mathrm{~cm})$ & 9.75 & 7.87 \\
$\mathrm{C}: \mathrm{N}$ ratio $(0-3 \mathrm{~cm})$ & -21.5 & -20.0 \\
$\delta^{13} \mathrm{C}(\%)$ & 8.04 & 8.68 \\
$\delta^{15} \mathrm{~N}(\%)$ & & \\
\end{tabular}

\subsection{Sediment characteristics}

Two cores per station were used to determine sediment characteristics. The upper $3 \mathrm{~cm}$ of each core was sliced off, homogenized and $10 \mathrm{~cm}^{3}$ of each slice subsampled and used for analysis. The porosity was calculated on sediment wet/dry measurements using an average sediment density of $2.55 \mathrm{~g} \mathrm{~cm}^{-3}$. Grounded freeze-dried sediment samples were measured for organic carbon content, molar $\mathrm{C}: \mathrm{N}$ ratio and background $\delta^{13} \mathrm{C}$ values with a Thermo Electron Flash EA 1112 analyser (EA) coupled to a Delta V IRMS. Sediment grain size distribution was assessed with a Malvern Mastersizer 2000 on freeze-dried sediment samples.

\subsection{Experimental incubations}

Four cores per station were incubated for 7 days: from STOMZ, two with the equivalent of $400 \mathrm{mg} \mathrm{C} \mathrm{m}^{-2} \mathrm{POM}$ and two with the equivalent of $400 \mathrm{mg} \mathrm{C} \mathrm{m}^{-2} \mathrm{DOM}$; and from SToutOMZ, two with the equivalent of $100 \mathrm{mg} \mathrm{C} \mathrm{m}^{-2} \mathrm{POM}$ and two with the equivalent $100 \mathrm{mg} \mathrm{C} \mathrm{m}^{-2}$ DOM. The selected tracer quantities represent 0.31 and $0.19 \%$ of the organic $\mathrm{C}$ present in the surface $3 \mathrm{~cm}$ of the sediment. The POM was resuspended in $0.2 \mu \mathrm{m}$ filtered natural seawater and then gently delivered to the sediment surface of each core via a long glass pipette, paying attention not to disturb the sediment. The DOM was dissolved in $0.2 \mu \mathrm{m}$ filtered natural seawater and subsequently introduced gently throughout the sediment profile down to approximately $4 \mathrm{~cm}$, with a micro-glass syringe via numerous injections of $10 \mu \mathrm{L}$ each, equally distributed over the surface of the core. The cores were sealed on the bottom and on the top with O-ring lids and incubated for 7 days under suboxic conditions $\left(6 \mu \mathrm{M} \mathrm{O}_{2}\right.$ for STOMZ and $125 \mu \mathrm{M} \mathrm{O}$ for SToutOMZ,), via bubbling with pre-made mixtures of air as done during pre-incubation (see above). To verify that the oxygen concentration in the core water of the different incubations was matching the de- sired ones, measurements were carried out with an oxygenoptode probe (Presens, Germany) following standard procedures of calibration, according to the optode manual, directly before and after the experiment. The out-flowing air of each core entered into two successively placed $\mathrm{CO}_{2}$ traps, which were connected to each other and changed every 3.5 days to prevent oversaturation. The $\mathrm{CO}_{2}$ traps were filled with a solution of Milli-Q water and $\mathrm{NaOH}$ (Kristensen et al., 1992) and were prepared in $500 \mathrm{~mL}$ sealed-off glass bottles with a screw-on septum cap. At the end of the incubation time, the cores were opened sequentially, oxygen concentration measurements done in the cores and water samples were taken.

Four cores per station were used to determine isotopic and biomass backgrounds. The natural abundance and background data have been presented and discussed by Pozzato et al. (2013).

\subsection{Sample processing}

At the end of the incubation, the overlying water of the cores and the content of the $\mathrm{CO}_{2}$ traps were filtered on $\mathrm{GF} / \mathrm{F}$ precombusted filters. The filters were then analysed for phospholipid fatty acids (PLFA) to estimate the water column bacterial contribution to OM degradation (see below). The sediment cores where then frozen in their coring tube. While frozen, the upper $10 \mathrm{~cm}$ of each core was cut off when still inside the coring tube with a hand saw for later sub-sampling. This procedure was preferred over normal slicing due to the extremely soft nature of the sediment. The intact core sections were stored in $\mathrm{a}-20^{\circ} \mathrm{C}$ freezer and transported to the laboratory at NIOZ Yerseke.

After arrival in the laboratory, four weeks later, the background and incubation cores were sliced while frozen in $2 \mathrm{~cm}$ intervals: 0-2 and 2-4 cm with a circular electric saw. While frozen, each slice was portioned as follows: one quarter (approximately $39 \mathrm{~mL}$ ) was analysed for bacterial PLFA, two quarters were used for faunal extraction and the remaining 
quarter was used for total lipids extraction and archaeal biomarkers (Lengger, 2013). The fatty acid subsample was freeze-dried and stored at $-20^{\circ} \mathrm{C}$ until further processing. The frozen subsamples for faunal analysis (for background and incubations cores) were immersed in a mixture of $40 \%$ buffered formaldehyde stained with rose bengal and allowed to thaw at room temperature. This was preferred over fixing and staining after defrosting to better preserve the fauna. The stained sediment was stored for 2 days at room temperature before sieving, to give the stain sufficient time to colour the animals.

\section{$2.7 \quad \delta^{13} \mathrm{C}$ isotope measurements}

\subsubsection{Bacteria}

The bacterial tracer incorporation was estimated through the isotope enrichment of bacterial-specific PLFAs (Boschker and Middelburg, 2002). Two main biomarkers were chosen for the analysis: iC15:0 and ai 15:0 because of their specificity for bacteria and presence in all samples. Fatty acids were extracted using the Bligh and Dyer extraction protocol and analysed using GC-c-IRMS (Middelburg et al., 2000) and $\delta^{13} \mathrm{C}$ values were corrected for the $\mathrm{C}$ addition during derivatization and also per PLFA-C content differences. Incorporation of ${ }^{13} \mathrm{C}$ into these bacterial PLFAs was converted to incorporation into bacterial biomass by assuming that the specific PLFAs represent $11 \%$ of all bacterial PLFAs, which in turn comprise $5.6 \%$ of total bacterial carbon (following Moodley et al., 2002). The conversion from PLFA gDW (grams Dry Weight) to bacterial biomass $\mathrm{m}^{-2}$ was done using determined sediment porosity values.

\subsubsection{Fauna}

Following rose bengal staining, the sediment was sieved on stacked 500 and $38 \mu \mathrm{m}$ sieves to separate macrofauna (retained on $500 \mu \mathrm{m}$ sieve) and meiofauna (retained on $38 \mu \mathrm{m}$ sieve). The meiofauna fraction was then further treated with Ludox (colloidal silica) centrifugation (Burgess, 2001) to separate the nematodes from the sediment. The division between macro- and meiofauna was based on size and not on genera. Foraminifera are usually considered to be part of meiofauna, but in our samples of approximately $78 \mathrm{~mL}$ of sediment, up to 100 specimens were retained on the $500 \mu \mathrm{m}$ sieve. Residues retained on both mesh sizes, containing the fauna and some sediment particles, were then hand-picked under a binocular microscope and the fauna was divided in branched and shelled Foraminifera, soft-bodied protists (both gromiids and allogromiids), polychaetes (other than Linopherus sp. which is listed separately due to its predominance in biomass), Linopherus sp., nematodes and "eukarya" (regrouping all other faunal species for which species determination was not done but consisting mostly of crustaceans). The fauna was transferred into pre-weighed silver cups, oven-dried $\left(50^{\circ} \mathrm{C}\right)$, decarbonated with $10 \% \mathrm{HCl}$ (slow addition for Foraminifera and checked under a binocular microscope to ensure that bubbling had finished) and again oven-dried. The silver cups were then weighed to establish the dry weight of the fauna and pinched closed. The samples were then analysed for carbon and nitrogen concentration and $\delta^{13} \mathrm{C}$ value with a Thermo Electron Flash EA 1112 analyser coupled to a Delta V. Faunal biomass was determined via dry weight and $\mathrm{C}$ content values from the IRMS, combined with measurements of faunal abundance from counting all specimens in the faunal sediment sample $(78 \mathrm{~mL})$ under the binocular microscope.

\subsection{Uptake calculations}

The relative uptake of the isotope tracer is presented in the $\Delta \delta^{13} \mathrm{C}$ notation, which represents the enrichment in $\delta^{13} \mathrm{C}$ of the sample in excess of its natural background value $\left(\delta^{13} \mathrm{C}_{\text {background }}\right)$, and is calculated as

$\Delta \delta^{13} \mathrm{C}_{\text {sample }}=\delta^{13} \mathrm{C}_{\text {sample }} \delta^{13} \mathrm{C}_{\text {background }}$.

The ${ }^{13} \mathrm{C}$ enrichment in at $\%(E)$ is calculated as

$E=F_{\text {sample }}-F_{\text {control }}$,

where

$F=\frac{{ }^{13} \mathrm{C}}{{ }^{13} \mathrm{C}+{ }^{12} \mathrm{C}}=\frac{R}{R+1}$

and

$R=\left(\frac{\delta^{13} \mathrm{C}}{1000}+1\right) \times R_{\mathrm{ref}}$,

with $R_{\text {ref }}=0.01118$. The uptake of ${ }^{13} \mathrm{C}$ tracer (I, $\mu \mathrm{g}$ tracer ${ }^{13} \mathrm{C} \mathrm{m}^{-2}$ ) is then calculated as the product of $E$ and biomass. The total uptake of the DOM and POM substrates ( $\mu \mathrm{g} \operatorname{tracer} \mathrm{C} \mathrm{m}^{-2}$ ) for both bacteria and fauna was then calculated according to Moodley et al. (2005a), by dividing the total ${ }^{13} \mathrm{C}$ tracer uptake (I) with the fractional abundance of ${ }^{13} \mathrm{C}$ in the tracers (i.e. 0.2 for POM, 0.18 for DOM). Please note that the presented data on relative and total uptake are calculated for each individual experimental core and then averaged. Biomass values are however the average of all cores (i.e. all experimental and background cores per station) since the larger area covered implies a better biomass estimate.

\subsection{Respiration measurements}

Water samples of $\sim 2 \mathrm{~mL}$ for analysis of DIC (dissolved inorganic carbon) from the $\mathrm{CO}_{2}$ traps (changed every 3 days) and the overlying water of the incubated cores were taken with a sterile plastic syringe, filtered on a GF/F filter attached to the syringe and injected into helium pre-flushed $5 \mathrm{~mL}$ glass vials, and were sealed with a crimp cap with rubber septum. 

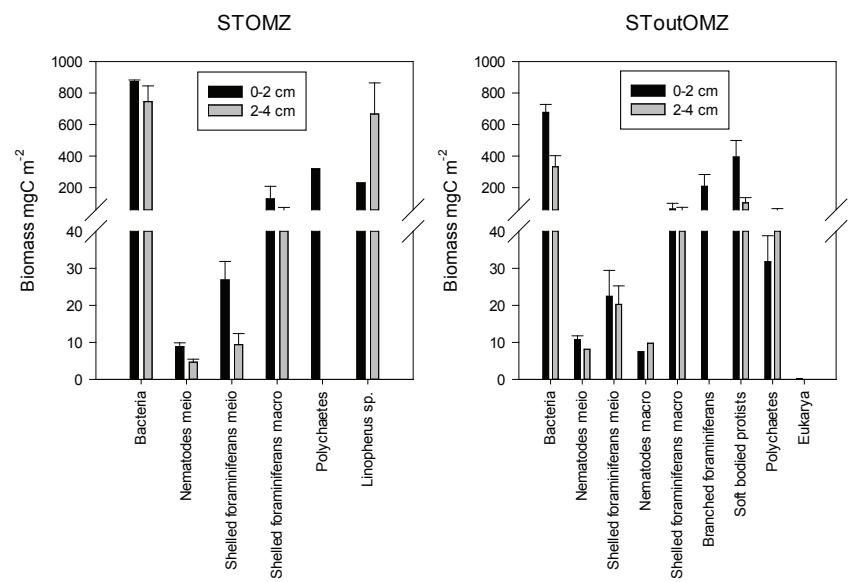

Fig. 2. Group-specific biomass presented per station. Values are averages of all cores, background and incubated ones, both treatments, to better account for heterogeneity. "Polychaetes" regroup all polychaete species other than Linopherus sp., "Eukarya" regroup all other faunal groups besides nematodes, foraminifera and polychaetes, for which no determination was done.

DIC samples were immediately acidified with $99 \% \mathrm{H}_{3} \mathrm{PO}_{4}$ $(10 \mu \mathrm{L}$ per $\mathrm{mL}$ sample) to stop biological activity and vials were stored upside down at $4{ }^{\circ} \mathrm{C}$ until analysis in the laboratory ( $\sim$ four weeks after sampling). Shortly before analysis, each vial was further acidified to convert any residual bicarbonate into $\mathrm{CO}_{2}$, which then accumulates in the vial headspace. The headspace was sampled using a glass syringe and $\mathrm{CO}_{2}$ concentration and isotope ratio of the gas were measured on a Thermo Electron Flash EA 1112 analyser coupled to a Delta V IRMS. Total respired ${ }^{13} \mathrm{C}$-DIC was determined by summing the values obtained from the overlying water and $\mathrm{CO}_{2}$ trap. The second $\mathrm{CO}_{2}$ trap in succession showed no to very limited ${ }^{13} \mathrm{C}$ enrichment in the DIC, which indicated that all DIC had been trapped and that the data from the second trap could safely be ignored in the calculations.

\section{Results}

\subsection{Sediment}

The sediment was very different between the two stations. SToutOMZ was mainly composed of light brown-gray and very compact clay, whereas at STOMZ it was dark brownblack, watery and fluffy, poor in clay but with a high content of foraminiferan shells and diatom frustules. The layering and burrows were still intact, indicating that no alteration of the sediment occurred during sampling and retrieval. The total organic carbon content and $\mathrm{C}: \mathrm{N}$ ratio were higher inside the OMZ, whereas the $\delta^{13} \mathrm{C}$ and $\delta^{15} \mathrm{~N}$ of the sediment inside and outside the OMZ were comparable (Table 1).
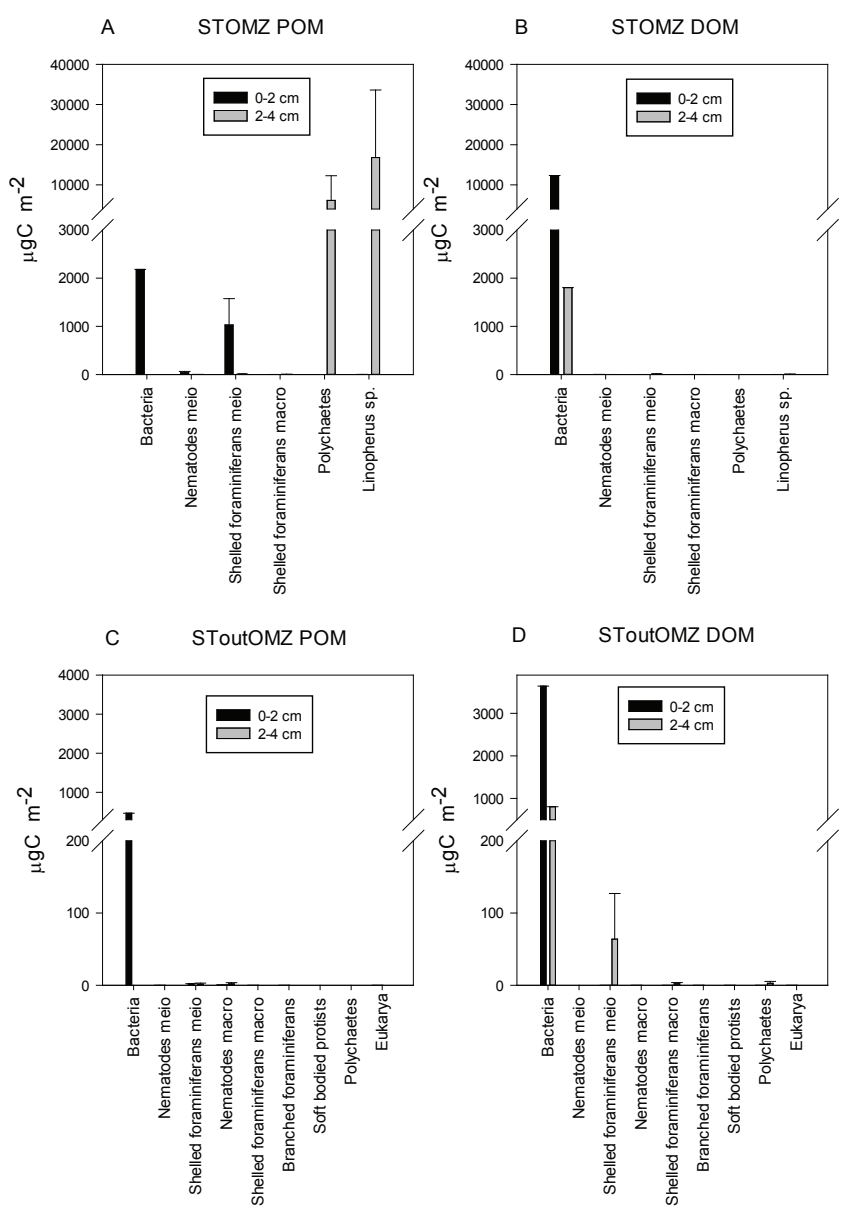

Fig. 3. Total tracer $\mathrm{C}$ incorporation in the stations divided per treatment. The term "Soft bodied protists" represents gromiids and allogromiids. "Polychaetes" regroup all polychaete species other than Linopherus sp., "Eukarya" regroup all other faunal groups besides nematodes, foraminifera and polychaetes, for which no determination was done.

\subsection{Benthic biomass}

Biomass data per layer and station of both incubated and background cores are shown in Fig. 2 as averages among treatments to account for sediment patchiness. For complementarity, depth $(0-4 \mathrm{~cm})$ integrated biomasses will be presented below. Bacterial biomass was $1000 \pm 120$ and $1600 \pm 110 \mathrm{mg} \mathrm{C} \mathrm{m}^{-2}$ respectively in SToutOMZ and STOMZ, meiofaunal nematode biomass was $19 \pm 1$ and $13 \pm 2 \mathrm{mg} \mathrm{C} \mathrm{m}^{-2}$, meiofaunal-sized shelled foraminiferan biomass was $42 \pm 12$ and $38 \pm 8 \mathrm{mg} \mathrm{C} \mathrm{m}^{-2}$. Macrofaunal-sized shelled foraminiferan biomass accounted for $118 \pm 58$ and $183 \pm 100 \mathrm{mg} \mathrm{C} \mathrm{m}^{-2}$ for SToutOMZ and STOMZ respectively; polychaetes biomass was $87 \pm 19$ and $897 \pm 299 \mathrm{mg} \mathrm{C} \mathrm{m}^{-2}$ with Linopherus sp. the most abundant species in STOMZ. Macrofaunal nematodes accounted for $17 \pm 0 \mathrm{mg} \mathrm{C} \mathrm{m}^{-2}$ in SToutOMZ but were found only in background cores at low biomass in STOMZ, macrofaunal 
Table 2. Relative uptake $\left(\Delta \delta^{13} \mathrm{C}\right)$ for POM and DOM treatment and natural abundances $\left(\delta^{13} \mathrm{C}\right)$ of the background samples for comparison. "n.f." means that no specimen of the group was found in the core layer. The terms "Soft bodied foraminifera" represents gromiids and allogromiids, "Polychaetes" regroup all polychaete species other than Linopherus sp.

\begin{tabular}{|c|c|c|c|}
\hline & $\begin{array}{c}\text { Relative Uptake } \\
\qquad \Delta \delta^{13} \mathrm{C} \% \text { o }\end{array}$ & $\begin{array}{c}\text { Relative Uptake } \\
\qquad \Delta \delta^{13} \mathrm{C} \% \text { o }\end{array}$ & $\begin{array}{l}\text { Natural Abundance } \\
\quad \delta^{13} \mathrm{C} \% \text { o }\end{array}$ \\
\hline & STOMZ POM & STOMZ DOM & Background \\
\hline \multicolumn{4}{|c|}{ Bacteria } \\
\hline $0-2$ & $80 \pm 23$ & $210 \pm 46$ & $-25.4 \pm 3.1$ \\
\hline $2-4$ & $0 \pm 0.0$ & $65 \pm 26$ & $-24.4 \pm 2.2$ \\
\hline \multicolumn{4}{|c|}{ Meiofauna } \\
\hline \multicolumn{4}{|c|}{ Nematodes } \\
\hline $0-2$ & $69 \pm 46$ & $5.9 \pm 10$ & $-22.3 \pm 1.0$ \\
\hline $2-4$ & $16 \pm 5.6$ & $0.4 \pm 0.9$ & $-22.2 \pm 1.1$ \\
\hline \multicolumn{4}{|c|}{ Shelled foraminifera } \\
\hline $0-2$ & $685 \pm 404$ & $3.6 \pm 3.4$ & $-23.7 \pm 0.1$ \\
\hline $2-4$ & $23 \pm 6.6$ & $9.3 \pm 0.8$ & $-11.1 \pm 3.0$ \\
\hline \multicolumn{4}{|c|}{ Soft-bodied foraminifera } \\
\hline $0-2$ & n.f. & n.f. & n.f. \\
\hline $2-4$ & n.f. & n.f. & n.f. \\
\hline \multicolumn{4}{|c|}{ Macrofauna } \\
\hline \multicolumn{4}{|c|}{ Shelled foraminifera } \\
\hline $0-2$ & $18 \pm 17$ & $5.2 \pm 2.7$ & $-21.5 \pm 0.1$ \\
\hline $2-4$ & $1.1 \pm 0.3$ & $11 \pm 10$ & $-20.8 \pm 0.7$ \\
\hline \multicolumn{4}{|c|}{ Linopherus sp. } \\
\hline $0-2$ & $44 \pm 44$ & $1.5 \pm 1.5$ & $-19.7 \pm 0.1$ \\
\hline $2-4$ & $136 \pm 116$ & $11 \pm 9.6$ & $-20.0 \pm 0.0$ \\
\hline \multicolumn{4}{|c|}{ Polychaetes } \\
\hline \multirow[t]{2}{*}{$0-2$} & $185 \pm 167$ & n.f. & $-16.9 \pm 0.0$ \\
\hline & $\begin{array}{l}\text { SToutOMZ } \\
\text { POM }\end{array}$ & $\begin{array}{l}\text { SToutOMZ } \\
\text { DOM }\end{array}$ & Background \\
\hline \multicolumn{4}{|c|}{ Bacteria } \\
\hline $0-2$ & $13 \pm 2.0$ & $40 \pm 3.3$ & $-21.8 \pm 0.8$ \\
\hline $2-4$ & no uptake & $26 \pm 26$ & $-23.2 \pm 1.1$ \\
\hline \multicolumn{4}{|c|}{ Meiofauna } \\
\hline \multicolumn{4}{|c|}{ Nematodes } \\
\hline $0-2$ & no uptake & $1.8 \pm 0.0$ & $-23.2 \pm 0.0$ \\
\hline $2-4$ & no uptake & no uptake & $-23.3 \pm 0.1$ \\
\hline \multicolumn{4}{|c|}{ Shelled foraminifera } \\
\hline $0-2$ & $3.9 \pm 1.8$ & $24 \pm 20$ & $24.2 \pm 0.0$ \\
\hline $2-4$ & $0.6 \pm 0.6$ & $40 \pm 39$ & $-24.7 \pm 2.1$ \\
\hline \multicolumn{4}{|c|}{ Soft-bodied foraminifera } \\
\hline $0-2$ & n.f. & n.f. & n.f. \\
\hline $2-4$ & n.f. & n.f. & n.f. \\
\hline \multicolumn{4}{|c|}{ Macrofauna } \\
\hline \multicolumn{4}{|c|}{ Nematodes } \\
\hline $0-2$ & $0.8 \pm 0.2$ & $2.2 \pm 2.0$ & $-17.4 \pm 2.1$ \\
\hline $2-4$ & n.f. & $2.5 \pm 1.6$ & $-17.2 \pm 0.0$ \\
\hline \multicolumn{4}{|c|}{ Shelled foraminifera } \\
\hline $0-2$ & $0.2 \pm 0.0$ & $0.4 \pm 0.2$ & $-20.3 \pm 0.2$ \\
\hline $2-4$ & n.f. & $0.5 \pm 0.5$ & $-20.0 \pm 0.1$ \\
\hline \multicolumn{4}{|c|}{ Branched foraminifera } \\
\hline $0-2$ & no uptake & $0.8 \pm 0.8$ & $-21.6 \pm 0.2$ \\
\hline $2-4$ & n.f. & n.f. & $-20.9 \pm 0.0$ \\
\hline \multicolumn{4}{|c|}{ Soft bodied foraminifera } \\
\hline $0-2$ & $1.0 \pm 1.0$ & $0.3 \pm 0.2$ & $-20.6 \pm 1.0$ \\
\hline $2-4$ & n.f. & $6.0 \pm 6.0$ & $-19.5 \pm 0.0$ \\
\hline Polyc & & & \\
\hline $0-2$ & $1.0 \pm 1.0$ & $0.3 \pm 1.0$ & $-19, .4 \pm 0.1$ \\
\hline $2-4$ & $7.3 \pm 7.3$ & $0.5 \pm 0.4$ & $-18.5 \pm 0.0$ \\
\hline
\end{tabular}



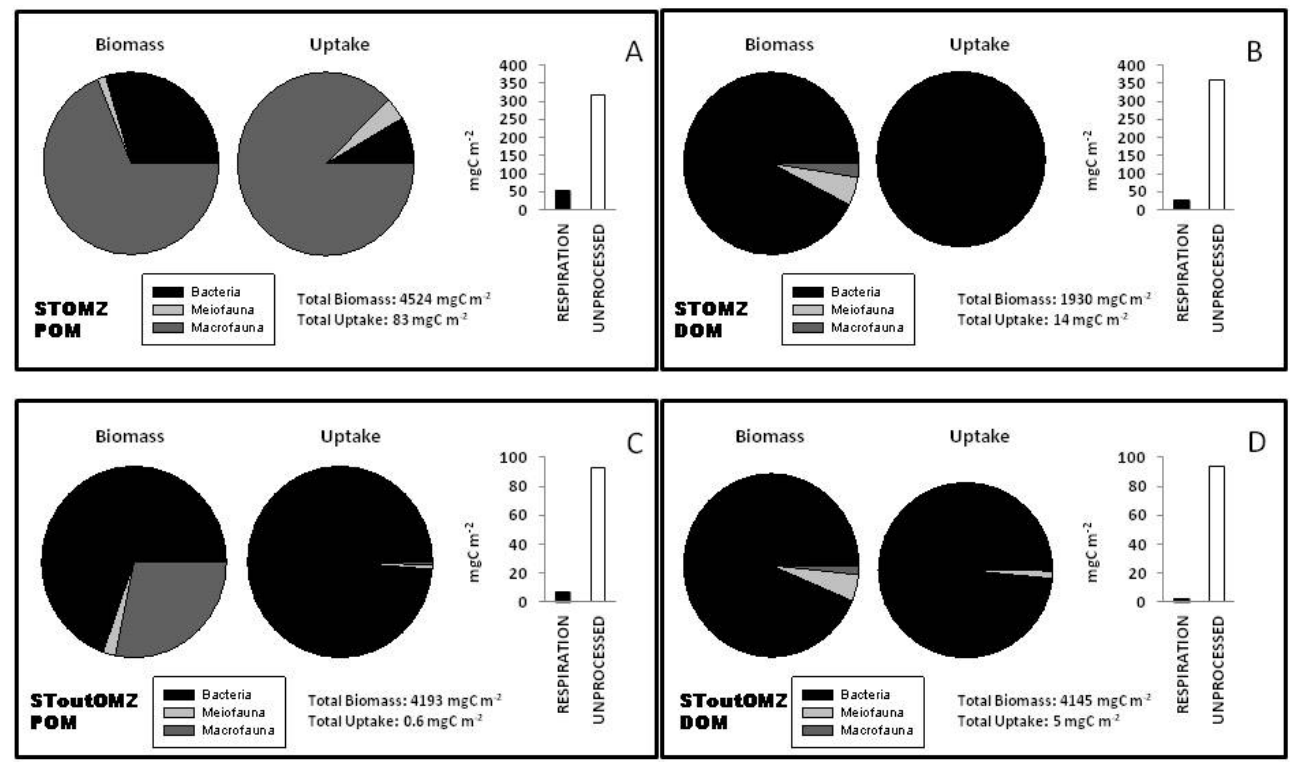

Fig. 4. Comparison between stations and treatments and overview of the benthic community structure and functioning. Biomass values are calculated per treatment and whole core to allow direct comparison with uptake values.

branched foraminifera and soft-bodied protists were found only in SToutOMZ where they accounted for $208 \pm 75$ and $497 \pm 138 \mathrm{mg} \mathrm{C} \mathrm{m}^{-2}$, respectively. Other eukaryotes accounted for $0.2 \pm 0 \mathrm{mg} \mathrm{Cm}^{-2}$ and were found only in SToutOMZ.

\subsection{OM incorporation}

Incorporation into biota of the two ${ }^{13} \mathrm{C}$ labelled OM types was evident, although the level of enrichment differed per station, benthic group and depth layer (Table 2, Fig. 3).

At STOMZ, the biota in the upper layer $(0-2 \mathrm{~cm})$ accounted for only a small part $\left(3247 \mu \mathrm{g} \mathrm{m}^{-2}\right.$ or $12 \%$ of the total uptake) of the POM uptake: bacteria incorporated $2181 \pm 1 \mu \mathrm{g} \mathrm{C} \mathrm{m}^{-2}$, meiofaunal nematodes $36.8 \pm 28$ and shelled foraminifera $1028 \pm 547 \mu \mathrm{g} \mathrm{m}^{-2}$, macrofaunal shelled foraminifera incorporated $0.13 \pm 0.12 \mu \mathrm{g} \mathrm{C} \mathrm{m}{ }^{-2}$ and Linopherus sp. accounted for $1.18 \pm 1 \mu \mathrm{g} \mathrm{C} \mathrm{m}^{-2}$. Almost all the POM incorporation took place in the deeper 2-4 cm layer $\left(23000 \pm 4000 \mu \mathrm{g} \mathrm{C} \mathrm{m}^{-2}\right.$ or $87 \%$ of the total uptake). Meiofaunal nematodes accounted for $2.66 \pm 0.5 \mu \mathrm{g} \mathrm{C} \mathrm{m}^{-2}$ and shelled foraminifera for $6.55 \pm 2.5 \mu \mathrm{g} \mathrm{m}^{-2}$, macrofaunal shelled foraminifera accounted for $4.83 \pm 3.4 \mu \mathrm{g} \mathrm{C} \mathrm{m}{ }^{-2}$, polychaetes for $6133 \pm 3050 \mu \mathrm{g} \mathrm{m}^{-2}$ and Linopherus sp. for $16807 \pm 840 \mu \mathrm{g} \mathrm{Cm}^{-2}$. The bacterial contribution to POM uptake in this deeper layer was negligible. DOM incorporation was strongly dominated by bacteria and thereby clearly different from that of the POM substrate. Most of the total uptake took place in the upper layer, $12314 \mu \mathrm{g} \mathrm{C} \mathrm{m}^{-2}$ (87\%): bacteria incorporated $12,312 \pm 7 \mu \mathrm{g} \mathrm{C} \mathrm{m}{ }^{-2}$, followed by meiofaunal nematodes with $2.33 \pm 0.28 \mu \mathrm{g} \mathrm{C} \mathrm{m}^{-2}$; macrofaunal shelled foraminifer- ans incorporated $0.02 \pm 0 \mu \mathrm{g} \mathrm{Cm}^{-2}$ and Linopherus sp. $0.05 \pm 0 \mu \mathrm{g} \mathrm{C} \mathrm{m}^{-2}$. Meiofaunal shelled foraminiferan contribution was negligible. In the deeper layer, $2-4 \mathrm{~cm}$, the uptake was much lower $\left(1818 \pm 13 \mu \mathrm{g} \mathrm{m}^{-2}\right.$ or $\left.13 \%\right)$ : bacteria again clearly dominated uptake $\left(1803 \pm 1 \mu \mathrm{g} \mathrm{C} \mathrm{m}^{-2}\right)$, while meiofaunal shelled foraminifera accounted only for $8.4 \pm 0.5 \mu \mathrm{g} \mathrm{C} \mathrm{m}^{-2}$, meiofaunal and macrofaunal nematodes had negligible uptake and macrofauna Linopherus sp. accounted for $6.1 \pm 0 \mu \mathrm{g} \mathrm{C} \mathrm{m}{ }^{-2}$.

At SToutOMZ, the largest part of the POM uptake was found in the upper layer: bacteria incorporated $466 \pm 0.2 \mu \mathrm{g} \mathrm{C} \mathrm{m}^{-2}$, meiofaunal shelled foraminifera $2.06 \pm 0 \mu \mathrm{g} \mathrm{C} \mathrm{m}^{-2}$, macrofaunal nematodes $0.42 \pm 0.4 \mu \mathrm{g} \mathrm{m}^{-2}$, other groups showed negligible uptake. In the deeper layer, only $0.6 \%$ of the total POM was taken up by meiofaunal shelled foraminifera $\left(1.47 \pm 1.4 \mu \mathrm{g} \mathrm{C} \mathrm{m}{ }^{-2}\right)$ and macrofaunal nematodes $\left(1.80 \pm 1.8 \mu \mathrm{g} \mathrm{C} \mathrm{m}^{-2}\right)$. DOM uptake in the upper layer was dominated by bacteria $\left(3637 \pm 2 \mu \mathrm{g} \mathrm{C} \mathrm{m}{ }^{-2}\right.$ ), with negligible uptake by the other groups $\left(<0.01 \mu \mathrm{g} \mathrm{C} \mathrm{m}^{-2}\right)$. This pattern was different in the deeper layer: bacteria incorporating $805 \pm 0.8 \mu \mathrm{g} \mathrm{C} \mathrm{m}^{-2}$, meiofaunal shelled foraminifera $63.7 \pm 62 \mu \mathrm{g} \mathrm{C} \mathrm{m}^{-2}$, macrofaunal shelled foraminifera $1.94 \pm 1.8 \mu \mathrm{g} \mathrm{C} \mathrm{m}^{-2}$ and polychaetes $2.63 \pm 2.6 \mu \mathrm{g} \mathrm{C} \mathrm{m}^{-2}$.

\subsection{Respiration}

Respiration of POM at STOMZ was twice as high as compared to DOM respiration, $54.5 \pm 10$ versus $26.9 \pm 9.5 \mathrm{mg} \mathrm{C} \mathrm{m}^{-2}$, respectively. The same pattern was seen at SToutOMZ, where respiration of POM and DOM were $6.82 \pm 1$ and $2.07 \pm 1.1 \mathrm{mg} \mathrm{C} \mathrm{m}^{-2}$, respectively. Most 
of the POM and DOM tracers were not processed within the 7 day incubation time, but respiration was the dominant fate of processed DOM and POM at both stations (Fig. 4), accounting for up to 13.6 and $6.73 \%$ of the added tracer on average for STOMZ POM and DOM treatment and 6.80 and $2.07 \%$ for SToutOMZ (Fig. 4).

\section{Methodological issues}

Experimental research on ocean margin and deep-sea sediments is challenging because of the limited amount of sample material available and the difficulties of mimicking in situ conditions (temperature and pressure). Our experiments were performed at in situ temperature, but on-board ship, implying that any differential pressure effect on prokaryotic vs. eukaryotic compartments might have affected our results. Experimental research on sediments underlying $\mathrm{OMZ}$ requires also incubation with controlled bottom-water oxygen levels. Oxygen concentrations during incubations were successfully maintained close to in situ conditions. The two substrates used were introduced in two different ways: POM was distributed on the core surface, DOM was injected throughout the $0-4 \mathrm{~cm}$ depth. This strategy was adopted to mimic best natural conditions, because POM is deposited on the sediment from the water column, while most DOM is generated within the sediments from sedimentary organic matter. However, this difference in spatial delivery patterns might have affected the availability of labelled DOM and POM to surface deposit feeders vs. subsurface feeders and microbes. We believe this to be a minor effect for macrofauna because macrofauna biomass (in particular Linopherus sp.) was higher in the $2-4 \mathrm{~cm}$ layer, but these animals were actively surfacing upon pulsed tracer delivery, hence making immediate use of the resource in the surface layer.

Our incubations lasted 7 days and this period might have been too short to allow complete upward transfer of bacterialderived carbon to meio- and macrofauna in these sites. However, shorter experiments executed in similar settings did report significant tracer transfer to bacteria and fauna (Moodley et al., 2005a, b; Woulds et al., 2007; Guilini et al., 2010). Nevertheless, a 7 day period is relatively short if transfers from bacteria to metazoan's consumers involve multiple benthic compartments (e.g. Nomaki et al., 2008). In that case longer lasting experiments might be needed to confirm our findings. Our community response study did not include archaea or mobile megafauna. No megafauna was found in the cores used for this study, therefore we cannot exclude potential bacterial ingestion by such deposit feeders (i.e. holothurians and echinoderms). Our analysis of the microbial community was limited to bacteria because in a companion study conducted at the same stations, Lengger (2013) showed that only bacteria and not archaea utilized the ${ }^{13} \mathrm{C}$ enriched POM and DOM, indicating bacteria as the dominant active microbial group.

\section{Discussion}

In most environmental settings, the majority of the OM that reaches the ocean floor is used by the benthic community for biomass production and respiration (Burdige, 2006). This processing is thought to occur essentially along two pathways in the benthic food web. The POM pathway involves metazoan ingesting of particulate detritus, while consortia of bacteria hydrolyse POM to DOM first, before taking it up. The DOM pathway involves the microbial incorporation of DOM directly, or after hydrolysis. Microbial carbon, produced through either the POM or DOM pathway, can be transferred to higher trophic levels via predation and grazing in accordance with the microbial loop concept. Woulds et al. (2009) reviewed isotope tracer experiments and showed that all benthic size classes are involved in the POM pathway, in shallow and deep ecosystems, spanning from low to high activity communities and from oxic to suboxic environments. The POM uptake rates in our experiments (Table 2 and Fig. 3), both here and in the companion study (Pozzato et al., 2013), confirm that all size classes take up recently deposited phytodetritus in Arabian Sea sediments. The biomass values of bacteria, protists and fauna in our stations (Fig. 2) were comparable to other deep-sea settings (Moodley et al., 2002, 2005b; Witte et al., 2003b; Woulds et al., 2009; Hunter et al., 2012), which confirms that the benthic community in Arabian Sea sediments underlying oxic and suboxic bottom water is well developed.

Although one decade of isotope tracer experiments has established that phytodetritus-derived carbon eventually ends up in all benthic size classes (Woulds et al., 2009), we have little understanding whether this represents direct access of consumers to POM and therefore direct incorporation of the tracer, or whether the POM uptake by fauna is mediated by bacteria. Here we directly address the question by focusing on the carbon flow in parallel incubations using complex ${ }^{13} \mathrm{C}$ enriched DOM and POM substrates and target both microbes and fauna.

In our experiments, the DOM tracer was quickly incorporated by bacteria but no appreciable uptake was seen by benthic meio- and macrofauna (Figs. 3, 4). This indicates not only absence of direct exploitation of DOM but also limited bacterivory by these two biotic compartments and the comparison of relative labelling $\left(\Delta \delta^{13} \mathrm{C}\right.$, Table 2$)$ of bacteria versus their potential consumers in other ecosystems (Hall and Meyer, 1998; Van Oevelen et al., 2006b) supports this finding. Few studies (Lee et al., 1966; Delaca et al., 1981; Delaca, 1982) reported foraminifera feeding directly on dissolved organic carbon, but it was not clear whether such uptake was direct or mediated by symbiotic bacteria. Our SToutOMZ samples also showed some enrichment in foraminifera (Fig. 3), thus we cannot exclude direct DOM assimilation or transfer through bacterivory to protists, the latter also suggested by Van Oevelen et al. (2006b) although in relative low amounts. Our findings therefore show that, at least in the short term, in 
the DOM pathway bacteria were not a principal food source for the fauna and that bacterial carbon was not transferred up the food web. Consequently we infer that the fauna uptake in our POM experiments, and most likely in other isotope tracer experiments, must also be due to direct ingestion of the POM substrate rather than ingestion of bacterial biomass. In the POM treatment, the $\Delta \delta^{13} \mathrm{C}$ values of fauna are much higher than those of bacteria (Table 2), further supporting that tracer incorporation occurred via direct substrate ingestion.

The two stations investigated differ not only in bottomwater dissolved oxygen concentrations, but also in grain size, sediment organic carbon, temperature (Table 1) and benthic community structure (Fig. 2). In the companion study Pozzato et al. (2013) showed that the communities were most efficient in processing particulate organic matter at in situ oxygen conditions and that organic matter supply rather than oxygen and temperature governed the higher faunal activity at STOMZ relative to SToutOMZ. This study shows that the transfer of bacterial carbon to protists and metazoan consumers was very limited at both stations although one might have anticipated more carbon flow via the DOM-bacteriametazoan pathway at STOMZ because of the higher carbon content and more active community (Pozzato et al., 2013).

Kemp (1990) reviewed the fate of benthic bacterial production in shallow/soft sediments and concluded that likely only a small fraction of bacterial production enters the macrofaunal food web (directly and indirectly) and that most bacterial production is remineralized and respired by a microbial food web. Later predation studies (Hondeveld et al., 1992; Starink et al., 1994; Hamels et al., 2001) further debunked the applicability of the microbial loop theory and Pomeroy's ideas for sediments, by not finding evidence of bacterial ingestion by their "thought to be" main grazers, protozoa, suggested as link between bacteria and fauna.

The limited bacterial-derived carbon transfer was confirmed experimentally by Van Oevelen and coauthors (2006a, b) who used in situ stable isotope pulse-chase experiments and modelling in a tidal mudflat. They concluded that some bacterial production was lost to the sediment via exchange processes and grazing by meio- and macrobenthos, but that its major fate was mortality (65\%), which induced recycling of bacterial biomass in the sediment. The same studies reported also that only a small portion (up to $11 \%$ ) of the faunal carbon requirements was met by bacterivory, irrespective of dwelling depth and organism size. Hence, they concluded that intertidal meio- and macrofauna depend primarily on carbon sources other than bacteria. Nomaki et al. (2006) conducted feeding experiments with deep-sea foraminifera using ${ }^{13} \mathrm{C}$-labelled bacteria and algae and found that these protozoa selectively ingested algae or randomly ingested sedimentary organic matter. No selective feeding on bacteria was observed, because bacteria were either not or to a very limited extent assimilated. Guilini et al. (2010) conducted similar experiments in the Arctic targeting nematode feeding habits and reached similar conclusions: bacteria were not a ma- jor food source for nematodes and the very limited amount of ${ }^{13} \mathrm{C}$ incorporated could not be attributed to bacterivory. These results by Van Oevelen et al. (2006a, b), Guilini et al. (2010) and Nomaki et al. (2006) support Kemp's conclusion that bacteria are not a major food source for protists and meio- and macrofauna and that faunal carbon requirements are not met by bacterial production. These and our experimental results disagree with other studies (Vanreusel et al., 1995; Iken et al., 2001; Hoste et al., 2007) that suggested transfer of carbon from bacteria to nematodes via direct predation from positive correlations between bacterial density and nematode abundance in the deep sea. Along this line, Ingels et al. (2010) found a preferential uptake of bacteria versus phytodetritus-derived carbon by nematodes, but the isotope enrichment of the nematodes was so low that the authors concluded that the contribution of nematodes to benthic mineralization was limited in deep polar seas. Hence, even though nematodes might be bacterivorous, upwards transfer of bacterial derived carbon via nematodes appears to be minimal.

It has been shown that bacterial standing stocks along a depth gradient of 0-6000 $\mathrm{m}$ appears quite stable in sediments (Rex et al., 2006). Hence, if it's not grazing controlling bacterial populations in sediments, then some other mechanism must be responsible. Recently Danovaro et al. (2008) suggested that viral infection controls bacterial production. In their recent review Rowe and Deming (2011) finally proposed a paradigm shift that is in line with most isotope tracer studies. Free-living heterotrophic microbes in marine sediments would play only a minor role in metazoan food webs, providing only a small fraction of metazoan's nourishment.

Finally, although our data are consistent with and support many recent studies showing a minor role for bacterivory in marine sediments, this does not apply to specific environments such as hydrothermal vents, colds seeps and other chemosynthetic systems in which primary production based on chemical energy provides the main energy source for entire food webs (Levin, 2005).

\section{Conclusions}

Accumulating evidence from the literature and our experimental results strongly suggest that bacteria are a carbon sink in the benthic food web of the Arabian Sea's OMZ sediments because no appreciable carbon transfer from bacteria up the food chain to meio- and macrofauna occurs via predation or grazing. This also implies that the POM and DOM processing pathways in this system are separated. The DOM pathway is limited to bacterial exploitation, since no other group showed any uptake of this resource, and no transfer of DOMderived carbon via bacterial grazing is observed, thus making this processing route a dead end. Within the POM pathway, there is competition for food, since bacteria as well as various faunal groups take up this resource, as shown in many 
short-term experiments. Similarly to what happens with the DOM, though, once POM is taken up by bacteria it is lost for faunal secondary production. Protists could have grazed upon bacteria to a minor extent but we could not investigate such predation, due to present lack of technical tools to do so in intact sediment cores. Our results from SToutOMZ indicate that direct DOM uptake by foraminifera may occur, as also found by others, which when predated by bigger fauna, might be an alternative route for carbon transport along the food chain. Evidently, there is great need for future investigation on the role of protozoans and protists in sedimentary food webs to be able to further constrain the apparently weak link between bacteria and protozoan and metazoan consumers in marine sediments.

Acknowledgements. This research was carried out as part of the PASOM project, which was funded by the NWO (Netherlands Organization for Scientific Research) under grant number 817.01.015 and the Darwin Center for Biogeosciences. We thank chief scientist G. J. Reichart and the crew of the RV Pelagia for logistic support during the 64PE301 cruise, the NIOZ-Yerseke Analytical Laboratory for analytical support, Pieter van Rijswijk for technical support and K. Koho for her precious advice on the foraminifera.

Edited by: H. Kitazato

\section{References}

Andersson, J. H., Woulds, C., Schwartz, M., Cowie, G. L., Levin, L. A., Soetaert, K., and Middelburg, J. J.: Short-term fate of phytodetritus in sediments across the Arabian Sea Oxygen Minimum Zone, Biogeosciences, 5, 43-53, doi:10.5194/bg-5-432008, 2008.

Azam, F., Fenchel, T., Field, J. G., Gray, J. S., Meyerreil, L. A., and Thingstad, F.: The ecological role of water-column microbes in the sea, Mar. Ecol.-Prog. Ser., 10, 257-263, 1983.

Blair, N. E., Levin, L. A., DeMaster, D. J., and Plaia, G.: The shortterm fate of fresh algal carbon in continental slope sediments, Limnol. Oceanogr., 41, 1208-1219, 1996.

Boschker, H. T. S. and Middelburg, J. J.: Stable isotopes and biomarkers in microbial ecology, Fems Microbiol. Ecol., 40, 8595, 2002.

Burdige, D. J.: Geochemistry of marine sediments, Princetown Univeristy Press, Princetown, 609 pp., 2006.

Burgess, B.: An improved protocol for separating meiofauna from sediments using colloidal silica sols, Mar. Ecol.-Prog. Ser., 214, 161-165, 2001.

Chrost, R. J.: Environmental control of the synthesis and activity of aquatic microbial ectoenzymes, in: Microbial Enzymes in Aquatic Environments, edited by: Chrost, R. J., Springer-Verlag New York, 29-59, 1991a.

Chrost, R. J.: Ectoenzymes in aquatic environments: microbial strategy for substrate supply, Int. Ver. Theor. Angew. Limnol. Verh., 24, 2597-2600, 1991b.

Cowie, G. L., Calvert, S. E., Pedersen, T. F., Schulz, H., and von Rad, U.: Organic content and preservational controls in surficial shelf and slope sediments from the Arabian Sea (Pakistan margin), Mar. Geol., 161, 23-38, 1999.

Danovaro, R., Dell'Anno, A., Corinaldesi, C., Magagnini, M., Noble, R., Tamburini, C., and Weinbauer, M.: Major viral impact on the functioning of benthic deep-sea ecosystems, Nature, 454, 1084-1088, 2008.

Delaca, T. E.: Use of dissolved amino acids by the foraminifer $\mathrm{No}$ todendrodes antarctikos, Am. Zool., 22, 683-690, 1982.

Delaca, T. E., Karl, D. M., and Lipps, J. H.: Direct use of dissolved organic carbon by agglutinated benthic foraminifera, Nature, 289, 287-289, 1981.

Demaison, G. J., and Moore, G. T.: Anoxic environments and oil source bed genesis, Am. Assoc. Pet. Geol. B., 64, 1179-1209, 1980.

Gaedicke, C., Schluter, H. U., Roeser, H. A., Prexl, A., Schreckenberger, B., Meyer, H., Reichert, C., Clift, P., and Amjad, S.: Origin of the northern Indus Fan and Murray Ridge, Northern Arabian Sea: interpretation from seismic and magnetic imaging, Tectonophysics, 355, 127-143, 2002.

Guilini, K., Van Oevelen, D., Soetaert, K., Middelburg, J. J., and Vanreusel, A.: Nutritional importance of benthic bacteria for deep-sea nematodes from the Arctic ice margin: Results of an isotope tracer experiment, Limnol. Oceanogr., 55, 1977-1989, 2010.

Hall, R. O. and Meyer, J. L.: The trophic significance of bacteria in a detritus-based stream food web, Ecology, 79, 1995-2012, 1998.

Hamels, I., Muylaert, K., Casteleyn, G., and Vyverman, W.: Uncoupling of bacterial production and flagellate grazing in aquatic sediments: a case study from an intertidal flat, Aquat. Microb. Ecol., 25, 31-42, 2001.

Hedges, J. I. and Keil, R. G.: Sedimentary organic matter preservation- An assessment and speculative systhesis-Closing comment, Mar. Chem., 49, 137-139, 1995.

Henrichs, S. M.: Early diagenesis of orcanic matter in marine sediments: progress and perplexity, Mar. Chem., 39, 119-149, 1992.

Hondeveld, B. J. M., Bak, R. P. M., and Vanduyl, F. C.: Bacterivory by heterotrophic nanoflagellates in marine sediments measured by uptake of fluorescently labelled bacteria, Mar. Ecol.-Prog. Ser., 89, 63-71, 1992.

Hoste, E., Vanhove, S., Schewe, I., Soltwedel, T., and Vanreusel, A.: Spatial and temporal variations in deep-sea meiofauna assemblages in the Marginal Ice Zone of the Arctic Ocean, Deep-Sea Res. Pt. I, 54, 109-129, 2007.

Hunter, C. J., Veuger, B., and Witte, U.: Macrofauna regulate heterotrophic bacterial carbon and nitrogen incorporation in lowoxygen sediments, ISME J., 6, 2140-2151 2012.

Iken, K., Brey, T., Wand, U., Voigt, J., and Junghans, P.: Food web structure of the benthic community at the Porcupine Abyssal Plain (NE Atlantic): a stable isotope analysis, Prog. Oceanogr., 50, 383-405, 2001.

Ingels, J., Van den Driessche, P., De Mesel, I., Vanhove, S., Moens, T., and Vanreusel, A.: Preferred use of bacteria over phytoplankton by deep-sea nematodes in polar regions, Mar. Ecol.-Prog. Ser., 406, 121-133, 2010.

Jeffreys, R. M., Wolff, G. A., and Cowie, G. L.: Influence of oxygen on heterotrophic reworking of sedimentary lipids at the Pakistan margin, Deep-Sea Res. Pt. II, 56, 358-375, 2009.

Jumars, P. A., Penry, D. L., Baross, J. A., Perry, M. J., and Frost, B. W.: Closing the microbial loop: dissolved organic carbon path- 
way to heterotrophic bacteria from incomplete ingestion, digestion and absorption in animals, Deep-Sea Res. Pt. A, 36, 483495, 1989.

Kemp, P. F.: Bacterivory by benthic ciliates: significance as a carbon source and impact on sediment bacteria, Mar. Ecol.-Prog. Ser., 49, 163-169, 1988.

Kemp, P. F.: The fate of benthic bacterial production, Rev. Aquat. Sci., 2, 109-124, 1990.

Koho, K. A., Nierop, K. G. J., Moodley, L., Middelburg, J. J., Pozzato, L., Soetaert, K., van der Plicht, J., and Reichart, G.J.: Microbial bioavailability regulates organic matter preservation in marine sediments, Biogeosciences, 10, 1131-1141, doi:10.5194/bg-10-1131-2013, 2013.

Kraal, P., Slomp, C. P., Reed, D. C., Reichart, G.-J., and Poulton, S. W.: Sedimentary phosphorus and iron cycling in and below the oxygen minimum zone of the northern Arabian Sea, Biogeosciences, 9, 2603-2624, doi:10.5194/bg-9-2603-2012, 2012.

Kristensen, E., Andersen, F. O., and Blackburn, T. H.: Effects of benthic macrofauna and temperature on degradation of macroalgal detritus - The fate of organic-carbon, Limnol. Oceanogr., 37, 1404-1419, 1992.

Lee, C.: Controls on organic carbon preservation: the use of stratified water bodies to compare intrinsic rates of decomposition in oxic and anoxic systems, Geochim. Cosmochim. Ac., 56, 33233335, 1992.

Lee, J.: A conceptual model of marine detrital decomposition and organisms associated with the process, in: Advances in aquatic microbiology, edited by: Droop, M. R. and Jannasch, H. W., Academic Press, 257-291, 1980.

Lee, J. J., McEnery, M., Pierce, S., Freudent, H. d., and Muller, W. A.: Tracer experiments in feeding littoral foraminifera, J. Protozool, 13, 659-670, 1966.

Lengger, S. K.: Production and preservation of archaeal glycerol dibiphytanyl glycerol tetraethers as intact polar lipids in marine sediments: Implications for their use in microbial ecology and TEX86 paleothermometry, PhD dissertation, Utrecht, 2013.

Levin, L. A.: Ecology of cold seep sediments: Interactions of fauna with flow, chemistry, and microbes, Oceanogr. Mar. Biol., Annu. Rev., 43, 1-46, 2005.

Levin, L. A., Blair, N., DeMaster, D., Plaia, G., Fornes, W., Martin, C., and Thomas, C.: Rapid subduction of organic matter by maldanid polychaetes on the North Carolina slope, J. Mar. Res., 55, 595-611, 1997.

Levin, L. A., Huggett, C. L., and Wishner, K. F.: Control of deepsea benthic community structure by oxygen and organic matter gradients in the eastern Pacific ocean, J. Mar. Res., 49, 763-800, 1991.

Levin, L. A., Whitcraft, C. R., Mendoza, G. F., Gonzalez, J. P., and Cowie, G.: Oxygen and organic matter thresholds for benthic faunal activity on the Pakistan margin oxygen minimum zone (7001100 m), Deep-Sea Res. Pt. II, 56, 449-471, 2009.

Mayer, L. M.: Extracellular proteolytic enzyme activity in sediments of an intertidal mudflat, Limnol. Oceanogr., 34, 973-981, 1989.

Mayer, L. M.: Surface area control of organic carbon accumulation in continental shelf sediments., Geochim. Cosmochim. Ac., 58, 1271-1284, 1994.
Middelburg, J. J. and Levin, L. A.: Coastal hypoxia and sediment biogeochemistry, Biogeosciences, 6, 1273-1293, doi:10.5194/bg-6-1273-2009, 2009.

Middelburg, J. J., Barranguet, C., Boschker, H. T. S., Herman, P. M. J., Moens, T., and Heip, C. H. R.: The fate of intertidal microphytobenthos carbon: An in situ ${ }^{13} \mathrm{C}$ labeling study, Limnol. Oceanogr., 45, 1224-1234, 2000.

Moodley, L., Middelburg, J. J., Boschker, H. T. S., Duineveld, G. C. A., Pel, R., Herman, P. M. J., and Heip, C. H. R.: Bacteria and Foraminifera: key players in a short-term deep-sea benthic response to phytodetritus, Mar. Ecol.-Prog. Ser., 236, 23-29, 2002.

Moodley, L., Middelburg, J. J., Herman, P. M. J., Soetaert, K., and de Lange, G. J.: Oxygenation and organic-matter preservation in marine sediments: Direct experimental evidence from ancient organic carbon-rich deposits, Geology, 33, 889-892, 2005a.

Moodley, L., Middelburg, J. J., Soetaert, K., Boschker, H. T. S., Herman, P. M. J., and Heip, C. H. R.: Similar rapid response to phytodetritus deposition in shallow and deep-sea sediments, J. Mar. Res., 63, 457-469, 2005b.

Moodley, L., Nigam, R., Ingole, B., Babu, C. P., Panchang, R., Nanajkar, M., Sivadas, S., van Breugel, P., van Ijzerloo, L., Rutgers, R., Heip, C. H. R., Soetaert, K., and Middelburg, J. J.: Oxygen minimum seafloor ecological (mal) functioning, J. Exp. Mar. Biol. Ecol., 398, 91-100, 2011.

Nomaki, H., Heinz, P., Nakatsuka, T., Shimanaga, M., Ohkouchi, N., Ogawa, N. O., Kogure, K., Ikemoto, E., and Kitazato, H.: Different ingestion patterns of C-13-labeled bacteria and algae by deep-sea benthic foraminifera, Mar. Ecol.-Prog. Ser., 310, 95108, 2006.

Nomaki, H., Ogawa, N. O., Ohkouchi, N., Suga, H., Toyotuku, T., Shimanaga, M., Nakatsuka, T., and Kitazato, H.: Benthic foraminifera as trophic links between phytodetritus and benthic metazoans: carbon and nitrogen isotopic evidence, Mar. Ecol.Prog. Ser., 357, 153-164, 2008.

Pomeroy, L.: The ocean's food web, a changing paradigm, BioScience, 24, 499-504, 1974.

Pozzato, L., Van Oevelen, D., Moodley, L., Soetaert, K., and Middelburg, J. J.: Carbon processing at the deep-sea floor of the Arabian Sea oxygen minimum zone: A tracer approach, J. Sea Res., 78, 45-58, 2013.

Rex, M. A., Etter, R. J., Morris, J. S., Crouse, J., McClain, C. R., Johnson, N. A., Stuart, C. T., Deming, J. W., Thies, R., and Avery, R.: Global bathymetric patterns of standing stock and body size in the deep-sea benthos, Mar. Ecol.-Prog. Ser., 317, 1-8, 2006.

Rowe, G. T. and Deming, J. W.: An alternative view of the role of heterotrophic microbes in the cycling of organic matter in deepsea sediments, Mar. Biol. Res., 7, 629-636, 2011.

Shimmield, G. B., Price, N. B., and Pedersen, T. F.: The influence of hydrography, bathymetry and productivity on sediment type and composition of the Oman Margin and in the Northwest Arabian Sea, Geological Society London, Special Publications, 49, 759769, 1990.

Starink, M., Krylova, I. N., Bargilissen, M. J., Bak, R. P. M., and Cappenberg, T. E.: Rates of benthic protozoan grazing on free and attached sediment bacteria measured with fluorescent stained sediment, Appl. Environ. Microb., 60, 2259-2264, 1994.

Van Oevelen, D., Middelburg, J. J., Soetaert, K., and Moodley, L.: The fate of bacterial carbon in an intertidal sediment: Model- 
ing an in situ isotope tracer experiment, Limnol. Oceanogr., 51, 1302-1314, 2006a.

Van Oevelen, D., Moodley, L., Soetaert, K., and Middelburg, J. J.: The trophic significance of bacterial carbon in a marine intertidal sediment: Results of an in situ stable isotope labeling study, Limnol. Oceanogr., 51, 2349-2359, 2006 b.

Vanreusel, A., Vincx, M., Schram, D., and Vangansbeke, D.: On the vertical distribution of the metazoan meiofauna in shelf break and upper slope habitats of the NE Atlantic, Int. Rev. Ges. Hydrobio., 80, 313-326, 1995.

Witte, U., Aberle, N., Sand, M., and Wenzhofer, F.: Rapid response of a deep-sea benthic community to POM enrichment: an in situ experimental study, Mar. Ecol.-Prog. Ser., 251, 27-36, 2003a.

Witte, U., Wenzhofer, F., Sommer, S., Boetius, A., Heinz, P., Aberle, N., Sand, M., Cremer, A., Abraham, W. R., Jorgensen, B. B., and Pfannkuche, O.: In situ experimental evidence of the fate of a phytodetritus pulse at the abyssal sea floor, Nature, 424, 763$766,2003 b$
Woulds, C., Cowie, G. L., Levin, L. A., Andersson, J. H., Middelburg, J. J., Vandewiele, S., Lamont, P. A., Larkin, K. E., Gooday, A. J., Schumacher, S., Whitcraft, C., Jeffreys, R. M., and Schwartz, M.: Oxygen as a control on seafloor biological communities and their roles in sedimentary carbon cycling, Limnol. Oceanogr., 52, 1698-1709, 2007.

Woulds, C., Andersson, J. H., Cowie, G. L., Middelburg, J. J., and Levin, L. A.: The short-term fate of organic carbon in marine sediments: Comparing the Pakistan margin to other regions, DeepSea Res. Pt. II, 56, 393-402, 2009. 